\title{
Radular morphology by using SEM in Pugilina cochlidium (Gastropoda: Melongenidae) populations, from Thondi coast-Palk Bay in Tamil Nadu-South East coast of India
}

\author{
Patricio De los Ríos ${ }^{a, b}$ (D), Laksmanan Kanagu ${ }^{c}$ (D), Chokkalingam Lathasumathic \\ and Chelladurai Stellac* (iD) \\ aDepartamento de Ciencias Biológicas y Químicas, Facultad de Recursos Naturales, Universidad Católica de Temuco, \\ Casilla 15-D, Temuco, Chile \\ bNúcleo de Estudios Ambientales, Universidad Católica Temuco, Casilla 15-D, Temuco, Chile \\ 'Department of Oceanography and Coastal Area Studies, Alagappa University, Thondi Campus, 623409, Tamil Nadu, India \\ *e-mail: stella2004@rediffmail.com; stella2004@alagappauniversity.ac.in
}

Received: February 17, 2019 - Accepted: June 19, 2019 - Distributed: November 30, 2019

(With 8 figures)

\begin{abstract}
Radula in all melongeninae species is rather uniform and characterized by bicuspid lateral teeth with strongly curved cusps and sub rectangular rachidians, bearing usually 3 cusps. The aim of the present study was to describe the radula of 2 Pugilina cochlidium populations using SEM. The radula in 2 species proves itself as a rachiglossate type showing the radular formula of $1+\mathrm{R}+1$. The first population hasthe central tooth wide with sharp cusps equal in length, emanate from posterior margin of tooth base. The lateral teeth have 2 cusps and are long, sharp, pointed and bent towards the rachidian tooth. Whereas the second population, the central tooth is narrow with sharp cusps equal in length, emanate from posterior margin of tooth base. The lateral teeth have 2 cusps and are broad, longer, sharp, pointed and bent towards the rachidian tooth. They are typically sickle shaped with broad strong base. In both populations the rachidian tooth is subquadrate with 3 big cusps in the middle, but in the second population the base of the rachidian is concave while in the first population it is straight. In the present study the median rachidian of the second population, has a broad basal region when compared to first. This similar observation has been made in Chicoreus virgineus ponderosus and Siratus virgineus ponderosus. In the present study, since 2 populations exhibit the same generalized rachiglossate pattern it does not offer much scope for systematic diagnosis below generic level.
\end{abstract}

Keywords: radula, SEM, Melongenidae, Pugilina cochlidium.

\section{Morfologia radular usando populações SEM em Pugilina cochlidium (Gastropoda: Melongenidae), da costa de Thondi-Palk Bay em Tamil Nadu-costa sudeste da Índia}

\begin{abstract}
Resumo
A rádula em todas as espécies de melongeninae é bastante uniforme e caracterizada por dentes laterais bicúspides com cúspides fortemente curvas e raquidianas sub-retangulares, portando geralmente 3 cúspides. O objetivo do presente estudo foi descrever a rádula de 2 populações de Pugilina cochlidium usando SEM. A rádula em 2 espécies mostra-se como um tipo rachiglossate mostrando a fórmula radular de $1+\mathrm{R}+1$. A primeira população tem o dente central largo com cúspides afiadas igual em comprimento, emana da margem posterior da base do dente. Os dentes laterais possuem 2 cúspides longas, pontiagudas, pontiagudas e dobradas em direção ao dente raquidiano. Enquanto a segunda população, o dente central estreito com cúspides afiadas igual em comprimento, emana da margem posterior da base do dente. Os dentes laterais têm 2 cúspides largas, longas, pontiagudas, pontiagudas e dobradas em direção ao dente raquidiano. Eles são tipicamente em forma de foice com ampla base forte. Em ambas as populações, o dente raquidiano é subquadrado com 3 grandes cúspides no meio, mas na segunda população a base do ráquidiano é côncava enquanto na primeira população é reta. No presente estudo, a mediana da raquidiana da segunda população apresenta uma ampla região basal quando comparada à primeira. Esta observação semelhante foi feita em Chicoreus virgineus ponderosus e Siratus virgineus ponderosus. No presente estudo, uma vez que 2 populações exibem o mesmo padrão de rachiglossato generalizado, ele não oferece muito espaço para o diagnóstico sistemático abaixo do nível genérico.
\end{abstract}

Palavras-chave: radula, SEM, Melongenidae, Pugilina cochlidium. 


\section{Introduction}

The morphology of the radula, the chitinous strip of teeth found in molluscs, has traditionally been one of the most commonly used sources of data for studies on molluscan systematics (Brusca and Brusca, 2002; Moore, 2006; Fernandes et al., 2013). The shape and form of molluscan radular teeth are typically unique to a species or genus, and some features of the radula such as tooth numbers have been used to investigate the higher level of molluscan taxonomic relationships (Roberts, 2000; Jörger and Schrödl, 2013; Kruta et al., 2013, 2014). Thus intraspecific variations in radular characteristics are important and must be documented for molluscan relationships. Scanning Electron Microscopy (SEM) is the most powerful tool in radular study. Research on functional morphology of the molluscs radula has focused attention on the obvious food-preparing and food gathering operation of the teeth and their relationship. This requires some knowledge on the radula and its functioning. The radula has also been recognized as an important morphological criterion for the taxonomic allocation of species. It shows general similarities on familial and generic levels with consistent differences on the species level. Their respective similarities and differences have been utilized to an increasing extent in the classification of muricid gastropods. There have been many studies on the gastropod radula, where the radular characters are generally considered constant within the species or that individual variation does not exceed the difference between species (Fretter and Graham, 1994). However, many studies have demonstrated that the radular characters are modified by many factors as seasonal changes, sexual differences, age were reported (Maes, 1966; Fujioka, 1984a, b, 1985a, b, c).

Arakawa (1958) has made some observation on the radulae of Purpura echinulata. (Lamarck, 1822). Griffiths (1961) has studied the sexual dimorphism in shell color is found in Cypraea gracilis (Gaskoin, 1848), where the females are red and the males brown. Arakawa (1962) has studied the radula of Japanese muricidae. Wu (1965a) has studied the radula of Taiwan muricid gastropods. Carriker (1969) has studied the SEM observation of gastropod radulae and its effectiveness in investigating the patterns of tooth and normal tooth functioning position. Runham-Norman (1969) has studied the chemical composition of the tooth. Isarankura and Runham-Norman (1968) have studied the growth and morphology of cusps and other structure of the radula. Runham-Norman (1969) has studied various gastropod radulae. Cernohorsky (1971) studied to exhibit sexual dimorphism in radular tooth row numbers in Pisania luctuosa (Tapparone-Canefri, 1880). Robertson (1971) studied the sexual dimorphism in the radula of Tricolia variabilis (Pease, 1861), where the males have fewer marginal teeth than the females. Robertson (1971) studied the sexual dimorphism in radular morphology of basal gastropod group, of trochoidean species T. variabilis. Solem (1972) has described the radular structure and functioning with SEM. Freeman and Silva (1973) have applied the SEM technique in describing the radulae of 2 marine gastropods. Solem (1974) have described the pattern of tooth structure in carnivorous snails with SEM. Fujioka (1982) has studied the sexual dimorphism in radular tooth of Drupella species. Fujioka (1984a, b) studied the radulae of 2 species of Cronia margariticola (Broderip et al., 1833) and Morula musiv (Kiener, 1835). Roller et al. (1984) have studied the regeneration of the proboscis, radula and odontophoral cartilage of the southern oyster drilled Thais. Houart (1992) has described the comparative morphology of 17 species of Chicoreus with SEM. Stella (1995) describing the radular morphology of Chicoreus species in Parangipettai waters. Guralnick and DeMaintenon (1997) have studied the development and homology of radular teeth, a case study using columbellid gastropods. DeMaintenon (2004) has studied the sexually dimorphic radular morphology in Euplica varians (Sowerby I, 1832) and Euplica versicolor (G.B. Sowerby, 1832). Annadurai (2006) has studied the radula structure of the venomous gastropod Conus textile in relation to feeding habits elucidated by scanning microscopy. Harding et al. (2008) have studied the radula morphology in Rapana venosa (Valenciennes, 1846) from Chesapeake Bay. Stella and Balalakshmi (2011) Using SEM studies on the radular morphology of Chicoreus species collected from Palk Bay in Tamil Nadu-South East Coast of India. Ravichandran (2012) Using SEM technique in describing the morphology of Radula of Chicoreus virgineus ponderosus (Röding, 1798) and Siratus virgineus ponderosus (Sowerby, 1879), from Thondi Coast, Palk Bay-Tamil Nadu South East Coast of India. Stella et al. (2014) using SEM technique in describing the morphology of radula of 2 forms of Chicoreus ramosus in Palk bay -south east coast of India. Stella et al. (2015) describing the Radular morphology by using SEM in Muricanthus kuesterianus (Tapparone-Canefri, 1875) Family: Muricidae, from Palk Bay-South East Coast of India. However no detailed work has been carried out so far. Hence the present attempt has been made to describe the morphological features of radula by using SEM in 2 Pugilina cochlidium (Linnaeus, 1758) populations from Thondi Coast-Palk Bay in Tamil Nadu, India.

\section{Material and Methods}

The specimens of 2 populations were collected from the trawlers (the specimens were deposited in Department of Oceanography and Coastal Area Studies, Alagappa University). The animals were brought to the laboratory and the outer hard shells were broken with a hammer. Care was taken not to damage the soft parts. The anterior portion of the proboscis was cut and used for the radular analysis with SEM. The radula removed from the proboscis was kept in a boiling tube containing alkaline solution. For radula extraction, live specimens were initially anaesthetized using 7.5\% Magnesium chloride to relax and loosen the body muscles attached to the shell and facilitate easy removal of the organism. Subsequently, an incision was made on the dorsal surface of the head to expose the radular sac 
located within the mantle cavity. The radular sac was transferred to $19 \% \mathrm{KOH}$ solution for digestion of radular tissue. Subsequently, the radula was washed with distilled water and dehydrated using alcohol. Dehydration was done by immersing the radula in increasing concentration of alcohol $(50,70,90,100 \%)$. Then the dehydrated radulae were brought to the next step of coating making them suitable for SEM observation. Initially, the radulae mounted on brass stubs with a double-sided tape were coated with gold and placed into the specimen chamber of the SEM (Roberts, 2000). Subsequently, photographs were taken at various magnifications depending on the size of the radula. Radula length and rachidian width were measured from the photographs. The terminology used in the description of radula follows Kool (1987). The SEM studies were made with the help of TESCAN make Scanning Electron microscope installed at CECRI, Karaikudi.

\section{Results}

The entire radula in matured animals measured about $1.0 \mathrm{~cm}$ in length in the first population., and in the second population it was $0.9 \mathrm{~cm}$. Radula of second population is of typical rachiglossate type with several rows of teeth and proves the radular formula is $1+\mathrm{R}+1$. Each row consists of a central and 2 laterals cusps. The length of radula in second population, measured about $1.8 \mathrm{~cm}$. (Figures 1-4), Photomicrograph shows that the central tooth is tricuspid having 3 large pointed sharp cusps. Central tooth wide with sharp cusps equal in length, emanate from posterior

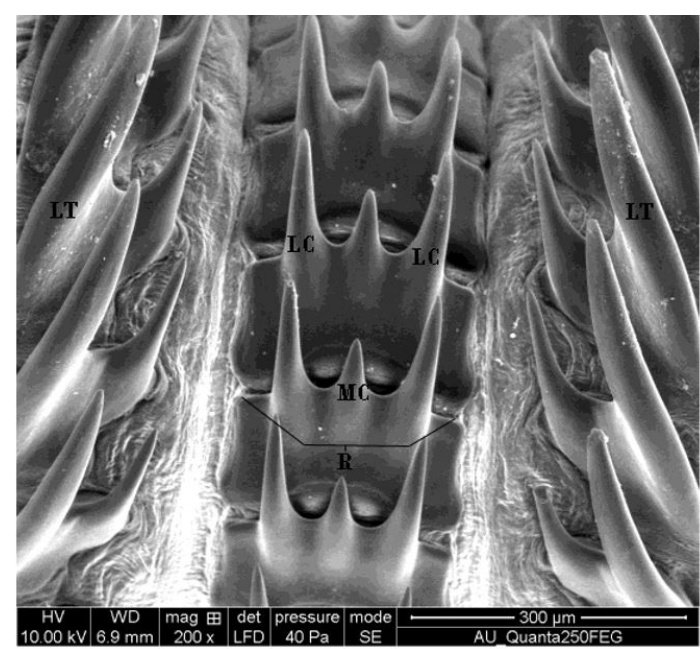

Figure 1. Anterior (left) region of radula of first population of $P$. cochlidium $. \mathrm{LT}=$ Lateral tooth; $\mathrm{LC}=$ Lateral cusp; $\mathrm{MC}=$ Median cusp; $\mathrm{R}=$ Rachidian toot.

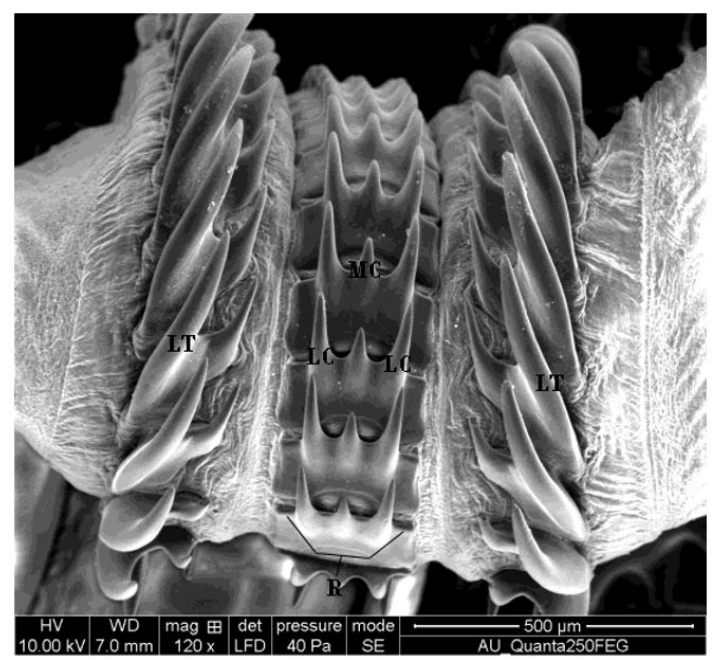

Figure 2. Posterior (right) region of radula of first population of $P$. cochlidium $. \mathrm{LT}=$ Lateral tooth LC $=$ Lateral cusp; $\mathrm{MC}=$ Median cusp; $\mathrm{R}=$ Rachidian toot.

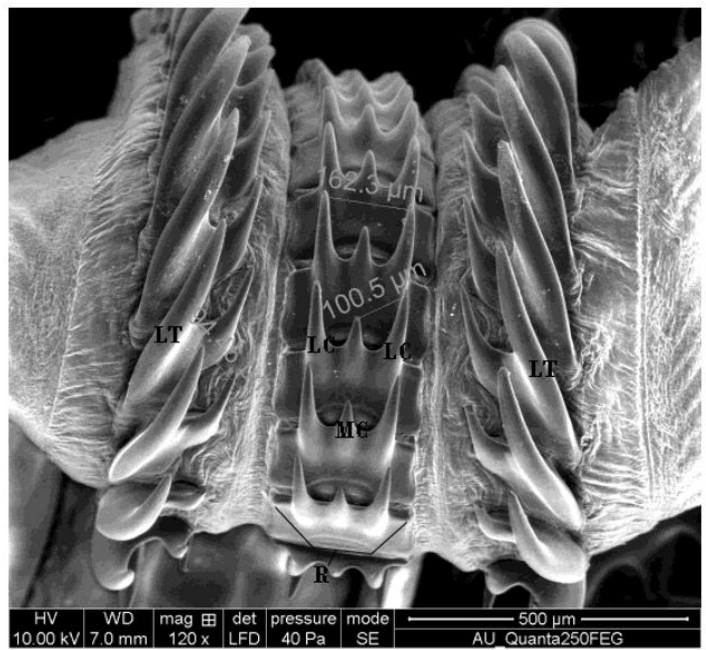

Figure 3. Rachidian (left) of $P$. cochlidium. $\mathrm{LT}=$ Lateral tooth; $\mathrm{LC}=$ Lateral cusp; $\mathrm{MC}=$ Median cusp; $\mathrm{R}=$ Rachidian.

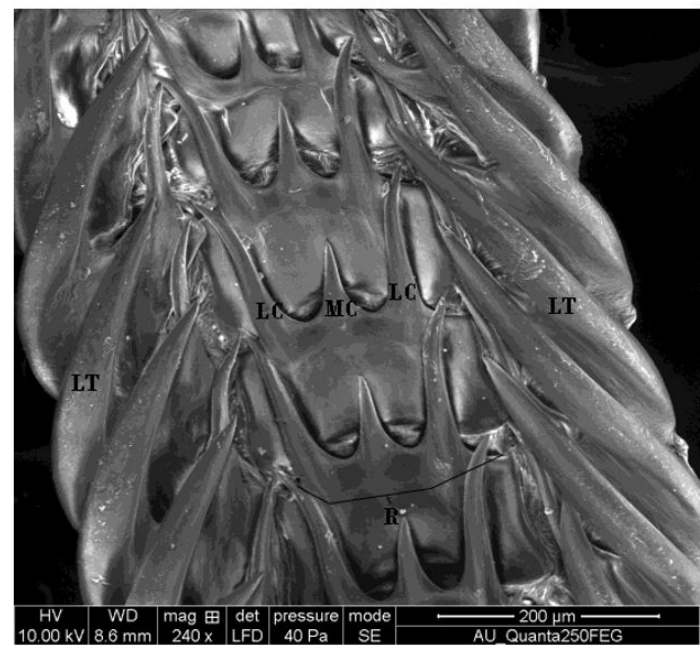

Figure 4. Lateral tooth (right) of $P$. cochlidium $. \mathrm{LT}=$ Lateral tooth; $\mathrm{LC}=$ Lateral cusp; $\mathrm{MC}=$ Median cusp; $\mathrm{R}=$ Rachidian. 
margin of tooth base. Anterior margin arcuate. The median cusp of the median rachidian tooth is some-what smaller than the lateral cusps. The median cusp is sharp and pointed straight towards anterior end. The lateral cusps are also sharp and pointed straight towards anterior end. The anterior region of the radula is different morphologically from the middle and posterior regions. The central cusp is smaller than lateral cusps. Both central and laterals of the rachidian tooth are sharp and straight along the axis of radula. The laterals are 2 in number occurring one on either side of the rachidian tooth. Lateral teeth bicuspidate, claw-like, with strongly curved outer cusps. The lateral teeth has 2 cusps are long, sharp, pointed and bent towards the rachidian tooth. In such condition all the teeth overlap the others that lie just in front of them. The rachidian teeth also cover one another.

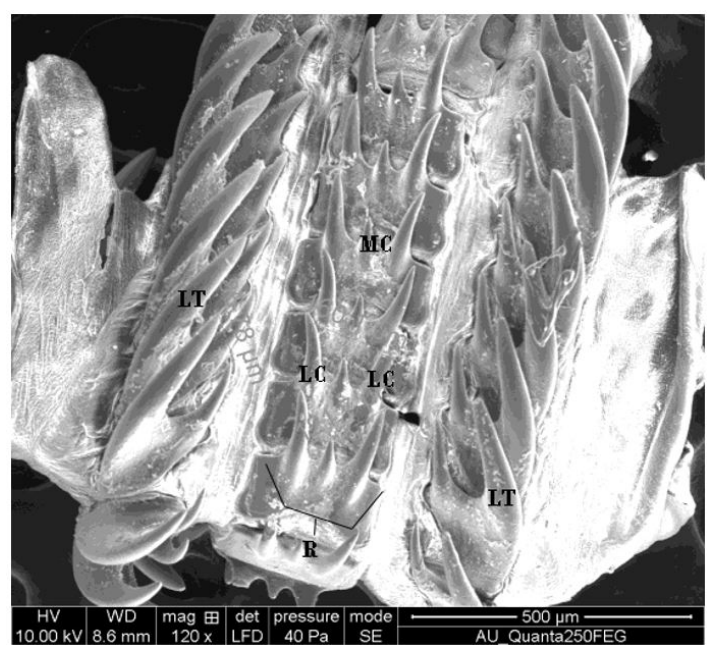

Figure 5. Anterior (left) region of radula of Pugilina sp. $\mathrm{LT}=$ Lateral tooth LC $=$ Lateral cusp $; \mathrm{MC}=$ Median cusp; $\mathrm{R}=$ Rachidian tooth.

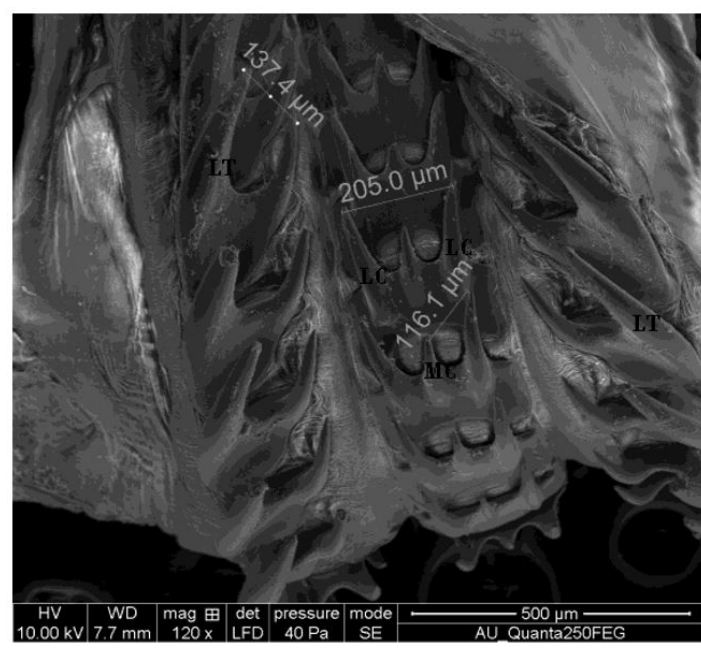

Figure 6. Posterior (right) region of radula of Pugilina sp. $\mathrm{LT}=$ Lateral tooth; $\mathrm{LC}=$ Lateral cusp; $\mathrm{MC}=$ Median cusp; $\mathrm{R}=$ Rachidian tooth
The radula of the second population resembles that of the first population in most details (Figures 5-8). But there are some apparent differences. In the second population, rachidian tooth has a broad base than that of first population. Central tooth wide with sharp cusps equal in length, emanate from posterior margin of tooth base. Anterior margin arcuate. The base of the median cusp is broad, short, sharp and pointed straight towards the anterior end. The lateral cusps are sharp and slightly bent outwards. The central cusps are longer than lateral cusps. Both central and laterals of the rachidian tooth are bent along the axis of radula. The lateral teeth have 2 cusps are broad, longer, sharp, pointed and bent towards the rachidian tooth. They are typically sickle shaped with broad strong base. The rachidian teeth also covers one another. In both species the rachidian tooth is subquadrate with 3 big cusps

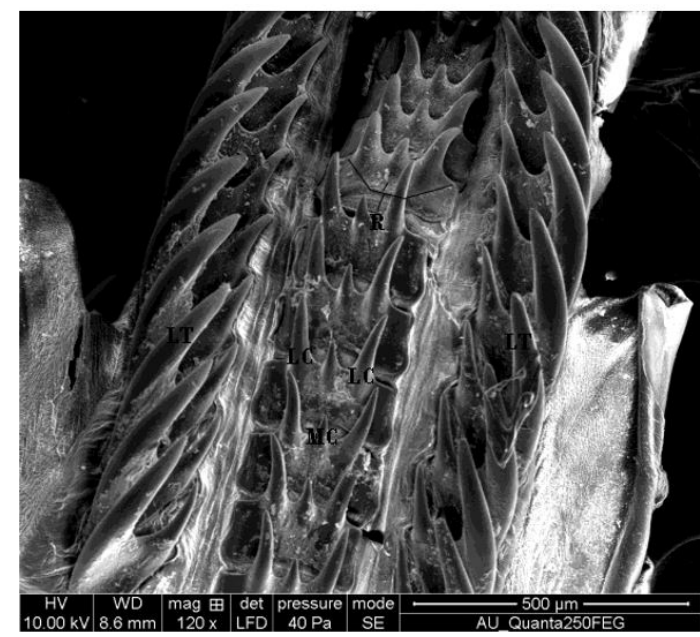

Figure 7. Rachidian tooth of second population of $P$. cochlidium. $\mathrm{LT}=$ Lateral tooth LC $=$ Lateral cusp; $\mathrm{MC}=$ Median cusp; $\mathrm{R}=$ Rachidian tooth .

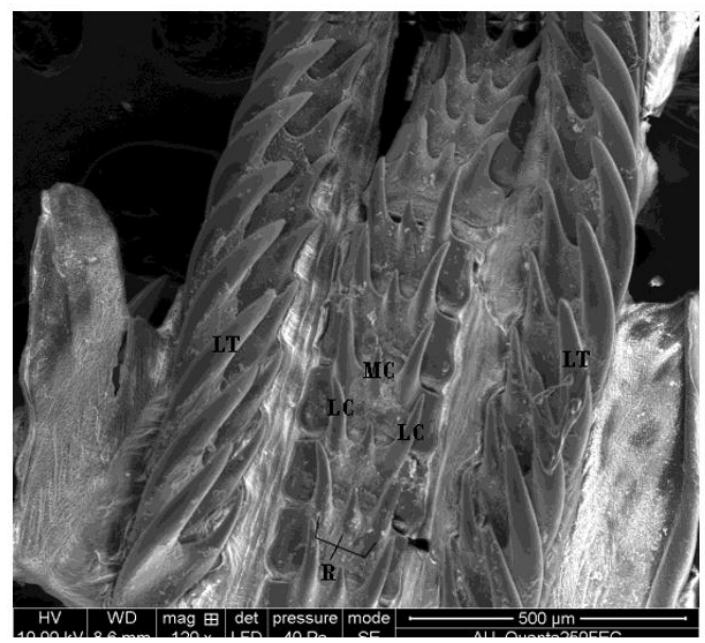

Figure 8. Lateral tooth of second population of P. cochlidium. $\mathrm{LT}=$ Lateral tooth; $\mathrm{LC}=$ Lateral cusp; $\mathrm{MC}=$ Median cusp; $\mathrm{R}=$ Rachidian tooth 
in the middle, but in the first population, the base of the rachidian is concave while in the second population is straight. The lateral teeth have 2 cusps inclined toward the central part of radular row, but in the first population the inner cusp is longer and slim than the second population.

\section{Discussion}

The radula is of typical rachiglossate type and the radular formula is $1+\mathrm{R}+1$ (Teso and Pastorino, 2011) this type of radula is highly evolved next to toxoglossate type (Eisapour et al., 2015) in general the central or rachidian tooth is tricuspid having 3 large pointed sharp cusps the median cusp of the median rachidian tooth is some what shorter than the lateral cusps the median cusp is sharp and pointed straight towards the anterior end (Teso and Pastorino, 2011; Eisapour et al., 2015). The lateral cusps are also sharp pointed straight towards the anterior end. The radula is a chitinous ribbon-like series of nearly colourless transverse tooth rows resting a top the radula membrane (Wu, 1965a, b; Radwin and Wells, 1968; Arularasan et al., 2011; Kruta et al., 2013; Lacerda et al., 2015).

Radula in all melongeninae species is rather uniform and characterized by bicuspid lateral teeth with strongly curved cusps and subrectangular rachidians, bearing usually 3 cusps. In 2 species the SEM observation on the radula elucidated several morphological details (Kantor et al., 2012). The central tooth in each transverse row is responsible for most of the rasping and physical shell removal during drilling while the marginal teeth synchronously tear flesh from the prey (Carriker et al., 1974; Pio et al., 2014). In these 2 species there is a close relationship between the radular ribbon and dental conformation. Similar observation has been made by Radwin and Wells (1968), Krutak (1977), Arularasan et al. (2011), Ravichandran et al. (2013). In muricid gastropods use the anterior teeth when drilling the holes of bivalve prey (Carriker, 1961, 1981; Fujioka, 1985a, b, c, d; Ravichandran et al., 2013). As the anterior teeth are worn down and replaced by younger teeth that are formed in the radular sac and gradually moved forward along the radula (Isarankura and Runham-Norman, 1968; Carriker, 1981; Ravichandran et al., 2013). In present study the radular ribbon is longer in first population when it compared to second population. This similar observation has been made in Ch. virgineus ponderosus and $S$. virgineus ponderosus by Ravichandran (2012) and Isarankura and Runham-Norman (1968). The reduction on the size of radular teeth seems to correlate with its environmental condition and food and feeding habits. Hemifusus ternatanus (Gmelin, 1791) ate the bivalve of Pinna pectinata was reported by Morton (1986). Many other melongenids have a similar diet of bivalves, including Hemifusus tuba (Gmelin, 1791) reported by Morton (1985), Busycon spp. reported by Kemp and Bertness (1984) and Melongena corona (Gmelin, 1791) reported by Bowling (1994), although the first population feeds upon barnacles was reported by Tan and Phuah (1999). In the present study the median rachidian of second population has a broad basal region when compared to first population. This similar observation has been made in Ch. virgineus ponderosus and Siratus virgineus ponderosus by Ravichandran (2012) and Ravichandran et al. (2013). In the present study since 2 species exhibit the same generalized rachiglossate pattern it does not offer much scope for systematic diagnosis below generic level.

\section{References}

ANNADURAI, D., 2006. Radula structure of the venomous gastropod Conus textile in relation to feeding habits - Electronic microscopy. Journal of Aquatic Biology, vol. 21, pp. 143-146.

ARAKAWA, K.Y., 1958. On the remarkable sexual dimorphism of the radula of Drupella. Venus, vol. 19, pp. 206-214.

ARAKAWA, K.Y., 1962. A study on the radulae of the Japanese Muricidae: the genera Purpura, Thais and Mancinella. Venus, vol. 22 , pp. 70-78.

ARULARASAN, S., KESAVAN, K. and LYLA, P.S., 2011. Scanning Electron Microscope (SEM) studies of radula of the dog conch Strombus canarium (Gastropoda: Prossobranchia: Strombidae). European Journal of Experimental Biology, vol. 1, pp. 122-127.

BOWLING, C., 1994. Habitat and size of the Florida crown conch (Melongena corona Gmelin): why big snails hang out at bars. Journal of Experimental Marine Biology and Ecology, vol. 175, no. 2, pp. 181-195. http://dx.doi.org/10.1016/00220981(94)90025-6.

BRUSCA, R.C. and BRUSCA, G.J., 2002. Invertebrates. Sunderland: Sinauer Associates, $904 \mathrm{p}$.

CARRIKER, M.R., 1961. Comparative functional morphology of boring mechanisms in gastropods. American Zoologist, vol. 1, no. 2, pp. 263-266. http://dx.doi.org/10.1093/icb/1.2.263.

CARRIKER, M.R., 1969. Excavalation of boreholes by the gastropod Urosalpinx an analysis by light and scanning electron microscopy. American Zoologist, vol. 9, no. 3, pp. 917-933. http:// dx.doi.org/10.1093/icb/9.3.917.

CARRIKER, M.R., 1981. Shell penetration and feeding by Naticacean and Muricacean predatory gastropods: a synthesis. Malacologia, vol. 20, pp. 403-422.

CARRIKER, M.R., SCHAADT, J.G. and PETERS, V., 1974. Analysis by slow motion picture photograph and scanning electron microscopy of radular function in Urosalpinx cinerea follyensis (Muricidae: Gastropoda) during shell penetration. Marine Biology, vol. 25, no. 1, pp. 63-76. http://dx.doi.org/10.1007/BF00395108.

CERNOHORSKY, W.O., 1971. Indo-Pacific Pisaniinae (Mollusca: Gastropoda) and related buccinid genera. Records of Auckland Institute and Museum, vol. 8, pp. 137-167.

DEMAINTENON, M., 2004. Sexually dimorphic radular morphology in Euplica varians and E. versicolor (Neogastropoda: columbellidae). Molluscan Research, vol. 24, no. 3, pp. 179-185. http://dx.doi.org/10.1071/MR04011.

EISAPOUR, M., SEYFABADI, S.S. and DAGHOOGHI, B., 2015. Comparaative radular morphology in some intertidal gastropods along Hormozgan Province, Iran. Aquaculture Research and Development, vol. 6, pp. 1000322. 
FERNANDES, M.R., PIMIENTA, A.D. and LEAL, J.H., 2013. Taxonomic review of triphorinae (Gastropoda Triphoridae) from the Vitória. Trindade Seamount Chain, southeastern Brazil. The Nautilus, vol. 127, pp. 1-18.

FREEMAN, S.E. and SILVA, S.R., 1973. SEM stuties on the radulae of two marine gastropods. Micron, vol. 4, pp. 247-255.

FRETTER, V. and GRAHAM, A., 1994. British prosobranch molluscs. London: The Ray Society, 820 p.

FUJIOKA, Y., 1982. On the secondary sexual characters found in the dimorphic radula of Drupella (Gastropoda: Muricidae) with reference to its taxonomic revision. Venus, vol. 40, pp. 203-223.

FUJIOKA, Y., 1984a. Sexually dimorphic radulae in Cronia margariticola and Morula musiva (Gastropoda: muricidae). Venus, vol. 43, pp. 315-330.

FUJIOKA, Y., 1984b. Sexually dimorphic radulae in Cronia margariticola and Morula musiva (Gastropoda: muricidae). Venus, vol. 43, pp. 315-330.

FUJIOKA, Y., 1985a. Seasonal aberrant radular formation in Thais bronni and T. clavigera (Gastropoda: muricidae). Journal of Experimental Biology and Ecology, vol. 90, no. 1, pp. 43-54. http://dx.doi.org/10.1016/0022-0981(85)90073-5.

FUJIOKA, Y., 1985b. Systematic evaluation of radular characters in Thaidinae (Gastropoda: muricidae). Journal of Science of the Hiroshima University Series B Division, vol. 31, no. 2, pp. 235-287.

FUJIOKA, Y., 1985c. Sexually dimorphic radulae in four species of Mancinella (Gastropoda: muricidae). Mukaishima Marine Biology Station, vol. 238, pp. 73-81.

FUJIOKA, Y., 1985d. Seasonal aberrant radular formation in Thais bronni (Dunker) and T. clavigera (Kuster) (Gastropoda: Muricidae). Journal of Experimental Biology and Ecology, vol. 90, no. 1, pp. 43-54. http://dx.doi.org/10.1016/0022-0981(85)90073-5.

GRIFFITHS, R.J., 1961. Sexual dimorphism in Cypraeidae. Proceedings of the Malacological Society of London, vol. 34, pp. 203-206.

GURALNICK, R.P. and DEMAINTENON, M.J., 1997. Development and homology of radular teeth: a case study using columbellid gastropods (Neogastropoda: Columbellidae). The Journal of Molluscan Studies, vol. 63, no. 1, pp. 65-77. http:// dx.doi.org/10.1093/mollus/63.1.65.

HARDING, J.M., GERA, S.M. and MANN, R., 2008. Radular morphology in veined rapa whelks Rapana venosa (Valenciennes,1846) (Gastropoda: Muricidae) from Chesapeake Bay, USA. The Nautilus, vol. 122, pp. 217-227.

HOUART, R., 1992. Description of a new species of Chicoreus (S.S.) (Gastropoda: Muricidae) from Kalimantan (Borneo). Apex, vol. 7, pp. 27-30.

ISARANKURA, K. and RUNHAM-NORMAN, W., 1968. Studies on the replacement of the gastropod radulae. Malacologia, vol. 7, pp. 71-91.

JÖRGER, K.M. and SCHRÖDL, M.S., 2013. How to describe a cryptic species? Practical challenges of molecular taxonomy. Frontiers in Zoology, vol. 10, no. 1, pp. 59. http://dx.doi. org/10.1186/1742-9994-10-59. PMid:24073641.

KANTOR, Y.I., PUILLANDRE, N., RIVASSEAU, A. and BOUCHET, P., 2012. Neither a buccinid nor a turrid: a new family of deep-sea snails for Belomitra P. Fisher, 1883 (Mollusca, Neogastropoda), with a review of recent Indo-Pacific species.
Zootaxa Monographs, vol. 3496, no. 1, pp. 1-64. http://dx.doi. org/10.11646/zootaxa.3496.1.1.

KEMP, P. and BERTNESS, M.D., 1984. Snail shape and growth rates evidence for plastic shell allometry in Littorina littorea. Proceedings of the National Academy of Sciences of the United States of America, vol. 81, no. 3, pp. 811-813. http://dx.doi. org/10.1073/pnas.81.3.811. PMid:16593415.

KOOL, S.P., 1987. Significance of radular characters in reconstruction of thaidid phylogeny (Neogastropoda: muricacea). The Nautilus, vol. 101, pp. 117-132

KRUTA, I., LANDMAN, N., ROUGET, I., CECCA, F. and TAFFOREAU, P., 2013. The radula of the late cretaceous scaphitid ammonite Rhaeboceras halli (Meek and Hayden, 1866). Paleontology, vol. 56, no. 1, pp. 9-14. http://dx.doi. org/10.1111/j.1475-4983.2012.01188.x.

KRUTA, I., LANDMAN, N.H., MAPES, R. and PRADEL, A., 2014. New insights into the buccal apparatus of the Goniatitina: palaeobiological and phylogenetic implications. Lethaia, vol. 47, no. 1, pp. 38-48. http://dx.doi.org/10.1111/let.12036.

KRUTAK, P.R., 1977. Gastropod radula: their potential in the fossil record. Transactions - Gulf Coast Association of Geological Societies, vol. 27, pp. 314-322.

LACERDA, L., RICHAU, C., AMARAL, C., SILVA, D., CARVALHO, E. and SANTOS, S., 2015. Ferrissia fragilis (Tryon, 1863): a freshwater snail cryptic invader in Brazil revealed by morphological and molecular data. Aquatic Invasions, vol. 10, no. 2, pp. 157-168. http://dx.doi.org/10.3391/ai.2015.10.2.04.

MAES, V.O., 1966. Sexual dimorphism in the radula of the muricidgenus Nassa. The Nautilus, vol. 79, pp. 73-80.

MOORE, J., 2006. An introduction to invertebrades. Cambridge: Cambridge University Press, 339 p. http://dx.doi.org/10.1017/ CBO9780511754760.

MORTON, B., 1985. Prey preference, capture and ration in Hemifusus tuba (Gmelin) (Prosobranchia: melongenidae). Journal of Experimental Biology and Ecology, vol. 94, no. 1-3, pp. 191-210. http://dx.doi.org/10.1016/0022-0981(85)90058-9.

MORTON, B., 1986. Prey preference and capture by Hemifusus ternatanus (Gastropoda: melongenidae). Malacological Review, vol. 19 , no. 2, pp. 107-110.

PIO, M.J., HERBERT, G.S. and PASTORINO, G., 2014. Developmental origins of complex radular characters in the Muricidae: the bifid rachidian edge. Invertebrate Biology, vol. 133, no. 1, pp. 64-73. http://dx.doi.org/10.1111/ivb.12040.

RADWIN, G.E. and WELLS, H.W., 1968. Comparative radular morphology and feeding habits of Muricid gastropods from the the Gulf of Mexico. Bulletin of Marine Science, vol. 18, no. 1, pp. 72-85.

RAVICHANDRAN, R., 2012. Taxonomy and biology of Chicoreus species (Class: Bivalvia: Family: Muricidae) from Thondi coast -Palk Bay in Tamil Nadu. Karaikudi: Alagappa University, 100 p. Ph.D. Thesis.

RAVICHANDRAN, R., CHELLAIDAN, D. and STELLA, C., 2013. Using sem technique in describing the morphology of Radula of Chicoreus virgineus ponderosus and Siratus virgineus ponderosus (Gastropoda: Muricidae) from Thondi Coast, Palk Bay-Tamil Nadu-South East Coast of India. World Journal of Fisheries and Marine Sciences, vol. 5, no. 2, pp. 182-187. http:// dx.doi.org/10.5829/idosi.wjfms.2013.05.02.7187. 
ROBERTS, A., 2000. A comparison of the feeding behaviour and the functional morphology of radula structure in Nudibranchs. Durham: Van Mildert College, University of Durham, 120 p. Thesis Masters Dissertation.

ROBERTSON, R., 1971. Sexually dimorphic archaeogastropods and radulae. Annual Repports of American Malacology United, vol. 1970, pp. 75-78.

ROLLER, R.A., GARTON, D.W. and STICKLE, V.B., 1984. Regeneration of the proboscis, radula and odontophoral cartilage of the southern oyster drill Thais haemastoma canaliculata (Gray) (Prosobranchia: Muricidae) after amputation. Bulletin of the American Malacological Union Incorporated, vol. 2, pp. 63-73.

RUNHAM-NORMAN, W., 1969. The use of SEM in the study of gastropod radulae: the radullae of Agriolimax reticulus and Nucella lapillus. In: Proceedings of Third European Malacological Congress Malacolgist, 1969. Buffalo: American Malacological Union, vol. 9, pp. 179-185.

SOLEM, A., 1972. Malacological applications of scanning electron microscopy-II Radullar structure and functioning. The Veliger, vol. 14, pp. 327-336.

SOLEM,A., 1974. Patterns of radular tooth structure in carnivorous land snails. The Veliger, vol. 17, pp. 81-88.

STELLA, C. and BALALAKSHMI, C., 2011. Using SEM studies on the radular morphology of Chicoreus species (Gastropods:Muricidae) collected from Palk Bay in Tamil Nadu-South East Coast of India. Journal of Ecology and Fisheries, vol. 4, pp. 73-78.
STELLA, C., 1995. Studies on the taxonomy and ecobiology of Chicoreus species from Parangipettai waters, South East Coast of India. Karaikudi: Annamalai University, 195 p. Ph.D. Thesis.

STELLA, C., LATHASUMATHI, C., CHELLAIYAN, D. and PAUL, P., 2014. Using SEM technique in describing the morphology of radula of two forms of Chicoreus ramosus (Gastropoda: Muricidae) in Palk bay -south east coast of India. International Journal of Current Zoological Research, vol. 2, pp. 1-4.

Stella, C., PAUl, P. and RAGUNATHAN, C., 2015. Describing the radular morphology by using SEM in Muricanthus kuesterianus (Tapparone-Canefri 1875) Family: Muricidae, from Palk Bay-South East Coast of India. Sustainability Agri Food and Environmental Research, vol. 3, no. 1, pp. 26-33. http://dx.doi. org/10.7770/safer-V3N1-art880.

TAN, K.S. and PHUAH, C.L., 1999. Diet and feeding habits of Pugilina cochlidium (Neogastropoda: Melongenidae) in Singapore. The Journal of Molluscan Studies, vol. 65, no. 4, pp. 499-501. http://dx.doi.org/10.1093/mollus/65.4.499.

TESO, V.S. and PASTORINO, G., 2011. A revision of the genus Olivancillaria (Mollusca: Olividae) from the southwestern Atlantic. Zootaxa, vol. 2889, no. 1, pp. 1-34. http://dx.doi.org/10.11646/ zootaxa.2889.1.1.

WU, S.K., 1965a. Comparative functional studies of the digestive system of the Muricid gastropods. Drupa ricina and Morula granulata. Malacologia, vol. 3, pp. 211-233.

WU, S.K., 1965b. Studies of the radulae of Taiwan Muricid Gastropods. Bulletin of the Institute of Zoology, Academia Sinica, vol. 4, pp. 95-106. 